\title{
Metaphor in the Bible
}

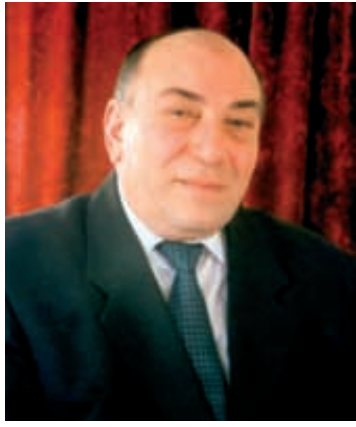

Gourgen Gevorgyan

$\mathrm{M}^{2}$ etaphor is one of the main stylistic devices of imagery. It is widely used in the Bible and the imagery of the Holy Book largely depends on this stylistic device.

Metaphor is a comparison reduced to a single word expressing similarity without the signs of comparison. A simile says that it is like this, a metaphor says it is this. In Luke 13:31-32, Jesus says of Herod: "Go and say to that fox." If he had said, "Go and tell that man that is like a fox," it would have been a simile, but Jesus used the forceful metaphor.

In 1 Corinthians 3:16 "You are a temple of God" is a metaphor. In Matthew 26:26-28 Jesus takes a loaf and says "this is my body" and he takes up a cup and says "this is my blood of the covenant": these are metaphors. How many controversies on the Lord's Supper would have been settled if brethren had realized that this was metaphorical language!

The Bible gives us not only examples of metaphors in words or sentences, but also metaphorical narratives. The way the author of Mark's gospel tells the stories of the two blind men, to whom Jesus gives sight, provides an illuminating example. The two stories frame the great central section of that gospel - a section that describes Jesus' final journey to Jerusalem, contains three solemn sayings about this impending death and resurrection, and speaks of discipleship as following Jesus on his journey.

Mark places the story of the blind man of Bethsaida at the beginning of this section. Jesus restores his sight in two stages. After the first, the blind man sees people but not clearly: "They look like trees walking”. After Jesus lays his hands on him a second time, the blind man sees "everything clearly".

At the end of the section is the story of a blind beggar named Bartimaeus. He cries out to Jesus, "Have compassion on me!" Jesus asks, "What do you want me to do for you?" In superbly evocative language, Bartimaeus expresses his desire: "Let me see again." Then we are told, "Bartimaeus regained his sight and followed Jesus on the way".

Unlike metaphors in fiction, which may maintain a strongly individual character, Biblical metaphors have a real basis. Although it would be rather difficult to show examples of allegories in the genealogy of Adam, Cain or Noah in Genesis, it is a fact and it has been proved that various ideas are contained in the names given in chronological sequence, conveying certain symbolic meanings to the names Noah (rest, 
repose), Eve (woman, life), Seth (given, lain, dead as opposed to Abel).

These are not ordinary names, but special codes, not only to describe these people, but also to denote stories. events and phenomena in another language. Being so, these names can be viewed as metonymies, although it is complicated to differentiate them from symbols. In some sense we can call them metaphors.

The Book of Genesis is comparatively free of allegories, though the plot (the creation of space) can be viewed as a huge metaphor, which reflects another reality - divinely beauliful and unknown. But the clear and realistic descriptions do not contain evident allegories.

In the beginning God created the heavens and the earth. The earth was without form and void; and darkness was on the face of the deep... (Gen 1:I-2)

Let the earth bring forth grass, the herb that vields seed, and the fruit tree that yields fiuit according to its kind. whose seed is in itself... (Gen 1:11)

As we continue the analysis of metaphors, it becomes apparent that though the Bible presents the most varied examples, it hardly uses them frequently. The Bible tends to represent real facts in simple, but beautiful narratives. The stylistic devices used should therefore "do their best" to coincide with the Biblical language. Metaphors and metonymies, despite being complicated means of expression, have their unique place and role in the Holy Scripture.

The earth trembled and the heavens dropped. (Judges 5:4)

The example emphasized is a metaphor. The dropping heavens are similar to a falling building.

And the spirit of the Lord began to move upon him at Mahaneh Dan between Zorah and Eshtaol. (Judges 5:4)

Moving of the spirit is used metaphorically. It is likened to the wandering of a man, Samson, at the beginning of the Book of Genesis: "And the spirit of God was hovering over the face of the waters. "(Gen 1:2) While in Genesis the spirit hovers on the waters, symbolizing the beginning of creation, in Judges it "moves upon him", as if to show that with the hand of Samson the people of Israel were to be liberated from the invaders.

In Ruth, Kings and other Books similar examples can be noticed. They become more frequent in the Psalms of David, Proverbs, Ecclesiastes and the Song of Solomon.

Now some examples from Proverbs:

The iniquities of the wicked ensnare him, and he is canght in the toils of the sin. (5:22)

The underlined abstract concepts in the passage are personified, because they are really alive and active slaves of a personified power - Satan. The quality of snaring iniquities means that man has to deal with evil and wickedness, which seize the pure soul, and which can catch man in the cords of his own sin. The moral of this passage is that man should be careful and wise if he wants to live an honest life and not to fall into temptations, as each of them can be harmful for him and send him to hell after death.

Examples from the New Testament:

You are the salt of the earth... (Matt 5:13)

You are the light of the world... (Matt 5:14) 
These two metaphors in one case show the quality of likening to salt, and in the other - to light. It is clear that likening should be understood abstractly, as a stylistic device.

If vour right hand causes you to sin, cut it off and throw it awav. (Matt 5:30)

In this case we have a personified verbal metaphor. Man performs most of his actions with the help of his right hand. The right side is considered to be more important, that is why the author uses this particular image.

He touched her hand and the fever lefi her: (Matt 8:15)

Here the quality of leaving, abandoning is attributed to the fever - which is not a casual means of expression. It is the demon of fever, which leaves Peter's mother-in-law after Jesus touches her. It is interesting to mention that unlike fictional personifications. which convey simply a circunstantial character, Biblical personifications possess their definite carriers (creators): these are either devilish or heavenly powers: demons, angels and their types.

But if your eye is bad, your whole body will be full of darkness. (Matt 6:23)

Through the religious symbolism of the human body: your eye is bad; your body will be fill of darkness, this speaks about sinning, yielding to temptations. In a general sense, this is a symbol, but from the point of view of linguistics, this is a metaphor. Such a natural phenomenon as darkness is attributed to the human body.

The son of Man will send his angels, and they will gather out of his kingdom all remptations and evildoers. (Matt 13:14)

In the metaphor emphasized, the abstract notm "temptations" is used in the plural and with a material quality 10 show that it is not simply a concept, but a direct quality, which causes different kinds of temptations. "Gathering of the temptations" is a metaphor on the level of linguo-expressiveness.

I have simned in betraying the innocent blood. (Matt 27:4)

These are the words of Judas, who regrets betraying his master and teacher for thirty silver coins. Imocem blood, to betray blood are expressions with metaphorical meaning. The concept of blood in its correlation with the quality (innocent) and (action) make up an expression, which can be called a double metaphor.

In him was life, and the life was the light of men. The light shines in the darkness, and the darkness has not overcome it. (John 1:4-5)

The life, which is the light for men, is lesus Christ himself. He brings life to the people. If we open up the expression "...darkness has not overcome it". we see that darkness is the Satan, who cannot overcome Jesus.

He says,

\section{I am the voice of one crying in the wilderness.}

Make straight the way of the Lord. (John 1:23)

The words emphasized are a metaphorical sentence, which could easily be turned into a simile: I am like the voice of one, crying in the wilderness. This would not be correct, as the inner expressiveness would be lost.

Behold, the Lamb of God, who takes away the sin of the world. (John 1:23) 
The first part of this saying can be viewed both as a metonymy (one of the names of Jesus) and a metaphor (the son of God). The second part is a metaphor. The function of going away is attributed to the sin.

I am the bread of life. (John 6:23)

Jesus speaks of himself. He gives life by giving bread, which he receives from the Lord.

I am the light of the world. (John 8:12)

Again a metaphorical expression. Why does Jesus liken himself to light? This is not the light of the sun, or the light of knowledge. This is the light of God, which gives eternal life.

I am the resurrection and the life, he who believes in me

though he die vet shall he live. (John 11:25)

Of course, and Jesus proves this by giving resurrection to Lazarus and taking him out of the grave.

Because, although they knew' God, thev did not glorify Him

as God, nor were they thankful, but became futile in their thought,

and their foolish hearts were darkened. (Rom 1:21)

For I do not desire, brethren, that you should be ignorant of this mystery,

lest you should be wise in your own opinion.

that blindness in part has happened to Israet

until the fullness of the Gentiles has come in. (Rom 11:25)

Therefore. purge out the old leaven, that you may be a new lump,

since you iruly are unleavened. For indeed Christ, our Passover,

was sacrificed for us. ( 1 Coll 5:7)

But above all these things put on love, which is the bond of perfection. (Coll 3:14)

Thus, the Bible is rich in all kinds of stylistic devices, among which metaphor has its particular place and role. Symbols are most characteristic of the Holy Scripture and they convey a special meaning to certain events, phenomena or even people. In the Bible everything is literally true, being the word of God. If we read the Bible with the Holy Spirit guiding us, there are no contradictions, no uncertainties. If you find a contradiction, the Holy Spirit is not with you.

\section{References:}

1. Galperin I.R. Stylistics. Moscow, 1977.

2. Milic L. Style and Stylistics. New York, 1967.

3. Akhmanova O., Zadomova V. Cross-Cultural Communication. Califonia, 1986.

4. Holy Bible, the Gideons International, New King James Version. 1982.

5. Hawkes T. Metaphor. London, 1972.

6. Metaphor and Thought (Ed. by A. Ortony). Canbridge University Press, 1979. 


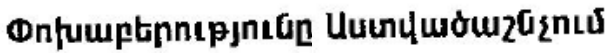

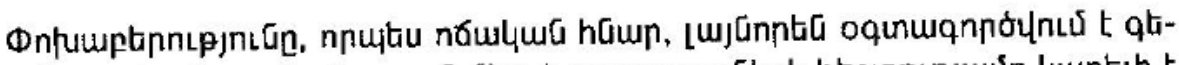

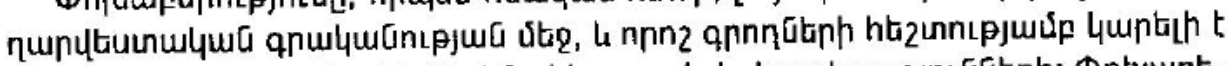

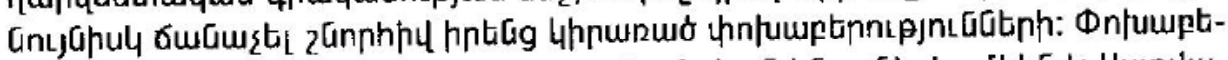

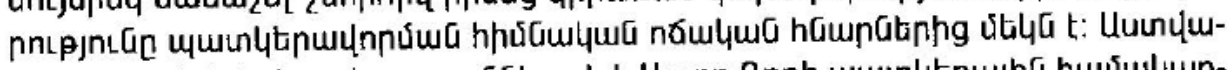

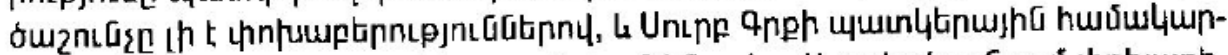

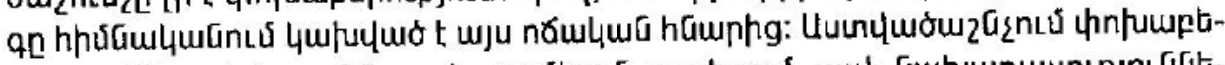

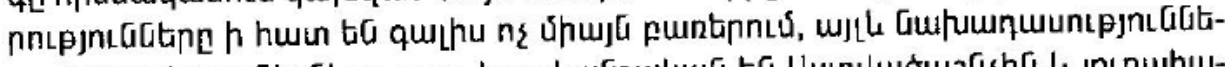

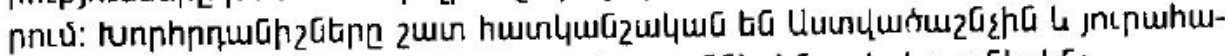

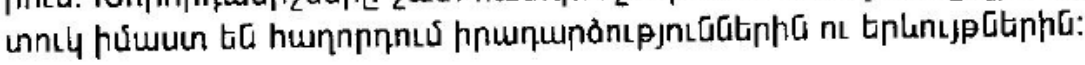

